\title{
Integrated Management of Chilli Leaf Curl Disease Complex in Ranchi Region in Jharkhand, India
}

\author{
N. Zeeshan and N. Kudada* \\ Department of Plant Pathology, Faculty of Agriculture, Birsa Agricultural University, \\ Ranchi, Jharkhand, India \\ *Corresponding author
}

\section{A B S T R A C T}

\begin{tabular}{|l|}
\hline Ke y w or d s \\
Chilli, Chilli leaf \\
curl, Integrated \\
management, Fruit \\
yield
\end{tabular}

Chilli is an economically important and widely cultivated crop of India. Chilli leaf curl disease complex is one of the major limiting factors in chilli production which is drastically decrease yield. The crop grown in Jharkhand usually suffers seriously from this disease. A field experiment on integration of insecticides as soil application with one and/or two sprayings each of other insecticides viz. Imidacloprid 17.8\% SL @ 0.003\%, Spinosad $45 \%$ SC@ 160 ml/ha and neem products viz., Neem Seed Kernel extract (NSKE 5\%)@5ml/ litre and Neem oil 0.03\% @5ml/litre was carried out during Rabi 2015-16 cropping season. Integration of soil application of Carbofuran 3G @ $30 \mathrm{Kg} / \mathrm{ha}$ plus two sprays of Imidacloprid 17.8\% SL@ 0.003\% recorded minimum disease incidence $(12.58 \%)$, highest green fruit yield of $101.56 \mathrm{q} / \mathrm{ha}$ and maximum disease reduction $(61.12 \%)$ and considerably enhanced plant vigour and green fruit yield of chilli. Maximum disease incidence $(32.35 \%)$ was observed in control with lowest yield of $57.56 \mathrm{q} / \mathrm{ha}$. Highest cost-benefit ratio of 1:3.60 was obtained by soil application of Carbofuran 3G @ $30 \mathrm{Kg} / \mathrm{ha}$ plus two sprays with Imidacloprid 17.8\% SL @ 0.003\%. Chilli leaf disease complex adversely affected yield attributing characters during Rabi cropping season.

\section{Introduction}

Chilli (Capsicum annuum L.) is considered as one of the most important vegetable and commercial spice crops grown throughout warm temperate, tropical and subtropical regions of the World. Chilli also called red pepper belongs to the genus Capsicum under the Solanaceae family. Besides traditional use of chilli as vegetables, spices, condiments, sauces and pickles, it is also being used in pharmaceuticals, cosmetics and beverages
(Tiwary et al., 2005). In Jharkhand, it is grown mostly in the districts of Ranchi, Hazaribag, Palamu and Giridih etc. Although there is a scope to enhance the productivity of chilli, a number of limiting factors have been attributed to the productivity. The damage caused by insect pests and mite is of paramount importance. The chilli leaf curl is most severe in India because of its complex nature. Virus diseases like mosaic and leaf curl complex caused heavy losses (Singh et al., 1998). Venkatesh et al., (1998) reported 
that chilli leaf curl complex was caused by chilli leaf curl geminivirus (CLCV) transmitted by white fly (Bemisia tabaci) also by thrips (Scirtothrips dorsalis) and mites (Polyphagotarsonemous latus). These are the major insects which besides sucking the sap of the plant parts, also act as vectors. Senanayake et al., (2006) reported that a very high disease incidence (upto $100 \%$ plants during December, 2004) in farmers' fields in Narwa and Tinwari villages at Jodhpur district, Rajasthan was observed. Overuse of pesticides has been often leading to the development of undesirable problems like destruction of natural enemies. It is essential to manage the vectors in an integrated manner in which botanicals and insecticides play an integral part and becoming more relevant in the present-day disease management scenario. Chilli leaf curl disease complex causes huge crop losses in Jharkhand state primarily due to attack of thrips, mites and white fly followed by invasion of chilli leaf curl virus. Considering the importance of the disease and losses, the present study was, therefore, undertaken to integrate insecticides and botanicals for the management of vector activities for reducing chilli leaf curl disease incidence in Ranchi region of Jharkhand.

\section{Materials and Methods}

To determine the efficacy of different insecticides and plant products on the incidence of leaf curl disease incidence fruit yield and yield attributing characters a field trial was conducted during Rabi, 2015-2016 cropping season in the glasshouse compound, Department of Plant Pathology, Birsa Agricultural University, Ranchi, Jharkhand, India. Field experiments were conducted in Randomised Block Design (RBD) with three replications and seven treatments. The trial was conducted during Rabi, 2015-16 cropping season by using the variety G-4. Thirty five days old seedlings were transplanted in $3 \mathrm{~m} \mathrm{x}$ $1.5 \mathrm{~m}$ sized plot with $50 \mathrm{~cm}$ x $50 \mathrm{~cm}$ spacing.
Soil application of Carbofuran 3G @ 30 Kg/ha was applied after 35 days of transplanting. After ten days of soil application of Carbofuran 3G@ $30 \mathrm{Kg} / \mathrm{ha}$ sprayings were done by insecticides and plant products. Control plots were maintained without soil application of Carbofuran. The required concentration of all the insecticides, plant products were spraying two times. The details of treatments were as follows: $\mathrm{T}_{1}$-Soil application of Carbofuran $3 \mathrm{G} @ 30 \mathrm{Kg} / \mathrm{ha}$ plus two sprays with Spinosad $45 \% \mathrm{SC}, \mathrm{T}_{2-}$ Soil application of Carbofuran 3G @ 30 Kg/ha plus two sprays with Imidacloprid $17.8 \% \mathrm{SL}$ $@ 0.003 \%, \mathrm{~T}_{3}$-Soil application of Carbofuran 3G@30 Kg/ha plus first spray with Spinosad 45\%SC@160ml/ha plus second spray with Imidacloprid $17.8 \%$ SL @ 0.003\%, $\mathrm{T}_{4}$-Soil application of Carbofuran 3G @ $30 \mathrm{Kg} / \mathrm{ha}$ plus two sprays with Need Seed Kernel Extract (NSKE) 5\% @ 5ml/lit, $\mathrm{T}_{5}$-Soil application of Carbofuran 3G @ $30 \mathrm{Kg} / \mathrm{ha}$ plus two sprays with Neem oil $0.03 \%$ @ $5 \mathrm{ml} /$ lit., $\mathrm{T}_{6^{-}}$Soil application of Carbofuran 3G@30 Kg/ha plus first spray with NSKE 5\%@5ml/lit. plus second spray with Neem oil 0.03\%@5ml/lit, T 7 -Control. The Disease incidence was recorded at frequent intervals after the appearance of disease symptoms. The percent disease incidence was recorded by counting the number of diseased plants in each treatment. Fruit yield was recorded from each treatment then it was converted into $\mathrm{q} / \mathrm{ha}$. Yield attributing characters were recorded at maturity stage of crop. Disease incidence was observed in each plot by counting total number of plants as well as diseased plants.

Percent disease incidence was calculated by following formula suggested by Nene (1972):

$\%$ Disease Incidence $=$

No. of Diseased units

Total no. of assessed units 
Percent disease reduction was calculated by following formula:

Percent disease reduction $=$

$\mathrm{C}-\mathrm{T}$

$\mathrm{C}$

Where, $\mathrm{C}$ is Percent disease incidence in untreated plants,

$\mathrm{T}$ is Percent disease incidence in treated plants.

The per cent increase of yield in treatment over control was calculated from the following formula (Vanisree et al., 2013).

Per cent increase of yield in treatment over control $=$

Yield in treatment - Yield in control

Yield in control

The fruit yield was recorded during the entire crop season and converted to per hectare. Yield was estimated after final picking of fruits. Cost - benefit ratio was calculated by using formula as follows:

Cost - benefit ratio $=$

Net profit (Rs.)

Cost of application

Net Profit $=$ Value of additional yield over control (Rs.) - Cost of application (Rs)

Following yield attributing characters were recorded as follows: 1. Plant height $(\mathrm{cm}), 2$. No. of branches/plant (no.), 3. Fruit length $(\mathrm{cm}), 4$. Fruit breadth $(\mathrm{cm}), 5$. Fruit weight (gm). Yield attributing characters were recorded from randomly selected five plants in each replication of each treatment at maturity stage of crop.

\section{Results and Discussion}

A field trial was carried out during Rabi, 2015-16 cropping season to determine the effect of integration of insecticides and botanicals against chilli leaf curl disease complex. All the treatments differed significantly when compared with control. The disease incidence was reduced by all the treatments in combination. Minimum disease incidence (12.58 percent) as recorded by the treatment $\mathrm{T}_{2}$ (Soil application of Carbofuran $3 \mathrm{G} @ 30 \mathrm{~kg} / \mathrm{ha}$ plus 2 sprays of Imidacloprid $17.8 \%$ SL@0.003\%) and maximum yield of $101.56 \mathrm{q} /$ ha which was statistically at par with treatment $\mathrm{T}_{3}$ (Soil application of Carbofuran 3G@30kg/ha plus $1^{\text {st }}$ spray with Spinosad 45\% SC @ 160ml/ha plus 2 ${ }^{\text {nd }}$ spray with imidacloprid $\quad 17.8 \% \quad$ SL@0.003\%)which recorded disease incidence of 14.64 percent. Maximum disease incidence 32.35 percent was recorded in control with lowest yield of $57.56 \mathrm{q} / \mathrm{ha}$. The treatment $\mathrm{T}_{2}$ (Soil application of Carbofuran 3G @30kg/ha plus 2 sprays of Imidacloprid $17.8 \%$ SL @0.003\%) recorded maximum disease reduction over control (61.12 percent) which was statistically superior to all other treatments followed by $\mathrm{T}_{3}$ (Soil application of Carbofuran $3 \mathrm{G}$ @ $30 \mathrm{~kg} / \mathrm{ha}$ plus $1^{\text {st }}$ spray with Spinosad $45 \%$ $\mathrm{SC} @ 160 \mathrm{ml} / \mathrm{ha}$ plus $2^{\text {nd }}$ spray with imidacloprid $\quad 17.8 \% \quad$ SL@0.003\%)(54.75 percent). The increase in yield over control was highest in $\mathrm{T}_{2}$ (76.44 percent) followed by $\mathrm{T}_{3}$ (68.73 percent) and $\mathrm{T}_{1}(61.38$ percent $)$ (Table 1 and Fig. 1).

Highest cost-benefit ratio of 1:3.60 was obtained when soil application of Carbofuran $3 \mathrm{G} @ 30 \mathrm{~kg} / \mathrm{ha}$ plus two sprays of Imidacloprid 17.8\%@0.003 percent $\left(\mathrm{T}_{2}\right)$ was applied. This $\mathrm{T}_{2}$ treatment also recorded net return of Rs. 34438 /- which was statistically 
superior to all other treatments followed by $\mathrm{T}_{3}$ (soil application of Carbofuran 3G @ 30 $\mathrm{kg}$ /haplus first spraywithSpinosad $45 \%$ SC @ $160 \mathrm{ml} / \mathrm{ha}$ plus second spray with Imidacloprid 17.8\% SL@0.003\%) (1:2.82). The lowest cost-benefit ratio (1:1.35) was recorded by soil application Carbofuran 3G @30kg/ha plus $1^{\text {st }}$ spay with NSKE 5\%@ $5 \mathrm{ml} / \mathrm{lit}$. plussecond spray with neem oil5\% @ 5ml/l. $\left(\mathrm{T}_{5}\right)$ (Table 2).

During Rabi, 2015-16 cropping season maximum mean plant height (39.87), mean no. of branches/ plant (5.7), mean length/fruit $(6.21 \mathrm{~cm})$, mean breadth/ fruit $(0.98 \mathrm{~cm})$ and weight/ plant (44.92 gm)were recorded in treatment $\mathrm{T}_{2}$ (soil application of Carbofuran 3G @ $30 \mathrm{~kg} / \mathrm{ha}$ plus two sprays of Imidacloprid 17.8\% SL@0.003 percent) which was followed $\mathrm{T}_{3}$ (soil application of Carbofuran 3G @ $30 \mathrm{~kg} / \mathrm{ha}$ plus first spray of Spinosad 45\%SC @160 ml/ha plus second spray of Imidacloprid 17.8\% SL @ 0.003\%).

All the treatments were found to be statistically superior over control (Table 3). Since, Imidacloprid is a new molecule hence no literature is available for supporting to results. The next effective treatments were $T_{3}$ followed by $\mathrm{T}_{1}$ and $\mathrm{T}_{4}$.

Table.1 Integrated disease management of leaf curl disease and green fruit yield of chilli

Rabi, 2015-16 cropping season

\begin{tabular}{|c|c|c|c|c|c|}
\hline Treatments & Dose & $\begin{array}{l}\text { Leaf curl } \\
\text { disease } \\
\text { incidence } \\
\quad(\%)\end{array}$ & $\begin{array}{l}\text { Disease } \\
\text { reduction } \\
\text { over } \\
\text { control } \\
(\%)\end{array}$ & $\begin{array}{l}\text { Yield } \\
\text { (q/ha) }\end{array}$ & $\begin{array}{l}\text { Increase } \\
\text { yield over } \\
\text { control } \\
(\%)\end{array}$ \\
\hline $\begin{array}{l}\text { Soil application of Carbofuran } 3 \mathrm{G} \\
\text { plustwo sprays ofspinosad } 45 \% \mathrm{SC}\end{array}$ & $\begin{array}{l}30 \mathrm{~kg} / \mathrm{ha}+ \\
160 \mathrm{ml} / \mathrm{ha}\end{array}$ & $\begin{array}{c}17.15 \\
(24.44)^{* *}\end{array}$ & 46.99 & 92.89 & 61.38 \\
\hline $\begin{array}{l}\text { Soil application of Carbofuran } 3 \mathrm{G} \\
\text { plus two sprays ofImidacloprid } \\
17.8 \% \mathrm{SL}\end{array}$ & $\begin{array}{c}30 \mathrm{Kg} / \mathrm{ha}+ \\
0.003 \%\end{array}$ & $\begin{array}{c}12.58 \\
(20.69)\end{array}$ & 61.12 & 101.56 & 76.44 \\
\hline $\begin{array}{l}\text { Soil application of Carbofuran } 3 \mathrm{G} \\
\text { plus } 1^{\text {st }} \text { spray withspinosad } 45 \% \mathrm{SC} \\
\text { plus } 2^{\text {nd }} \text { spraywith Imidacloprid } \\
17.8 \% \mathrm{SL}\end{array}$ & $\begin{array}{c}30 \mathrm{~kg} / \mathrm{ha}+ \\
160 \mathrm{ml} / \mathrm{ha}+ \\
0.003 \%\end{array}$ & $\begin{array}{c}14.64 \\
(22.48)\end{array}$ & 54.75 & 97.12 & 68.73 \\
\hline $\begin{array}{l}\text { Soil application of Carbofuran } 3 \mathrm{G} \\
\text { plus two sprays with NSKE } 5 \%\end{array}$ & $\begin{array}{c}30 \mathrm{Kg} / \mathrm{ha}+ \\
5 \mathrm{ml} / \mathrm{lit}\end{array}$ & $\begin{array}{c}18.58 \\
(25.47)\end{array}$ & 42.56 & 90.00 & 56.36 \\
\hline $\begin{array}{l}\text { Soil application of Carbofuran } 3 \mathrm{G} \\
\text { plus two sprays with Neem oil } \\
0.03 \%\end{array}$ & $\begin{array}{l}30 \mathrm{Kg} / \mathrm{ha}+ \\
5 \mathrm{ml} / \mathrm{lit}\end{array}$ & $\begin{array}{c}21.86 \\
(27.84)\end{array}$ & 32.43 & 93.56 & 62.54 \\
\hline $\begin{array}{l}\text { Soil application of Carbofuran } 3 \mathrm{G} \\
\text { plus } 1^{\text {st }} \text { spray with NSKE } 5 \% \text { plus } \\
2^{\text {nd }} \text { spray with Neem oil } 0.03 \%\end{array}$ & $\begin{array}{c}30 \mathrm{Kg} / \mathrm{ha}+ \\
5 \mathrm{ml} / \mathrm{lit}\end{array}$ & $\begin{array}{c}19.02 \\
(25.71)\end{array}$ & 41.20 & 88.89 & 54.43 \\
\hline $\mathrm{T}_{7-}$ Control & & $\begin{array}{c}32.35 \\
(34.64)\end{array}$ & & 57.56 & \\
\hline S.E.m \pm & & 1.07 & & 0.364 & \\
\hline C.D. at $5 \%$ & & 3.32 & & 1.135 & \\
\hline C.V. \% & & 7.13 & & 15.81 & \\
\hline
\end{tabular}

** Figures in parentheses are arcsine transformed values 
Table.2 Cost-benefit ratio of integrated disease management

\begin{tabular}{|c|c|c|c|c|c|c|c|c|}
\hline & & & & & Rabi, 2 & 015-16 crop & ing seasc & \\
\hline \multicolumn{2}{|r|}{ Treatments } & Dose & $\begin{array}{c}\text { Yield(q/ } \\
\text { ha) }\end{array}$ & $\begin{array}{l}\text { Additional } \\
\text { yield over } \\
\text { control } \\
\text { (q/ha) }\end{array}$ & $\begin{array}{c}\text { Value of } \\
\text { additional } \\
\text { Yield @ } \\
\text { Rs 1000/q }\end{array}$ & $\begin{array}{c}\text { Cost of } \\
\text { insecticidal } \\
\text { application } \\
\text { (Rs) }\end{array}$ & $\begin{array}{l}\text { Net } \\
\text { return/ } \\
\text { ha } \\
\text { (Rs) }\end{array}$ & $\begin{array}{c}\text { Cost } \\
\text { benefit } \\
\text { ratio } \\
\text { (Rs) }\end{array}$ \\
\hline $\mathbf{T}_{1}$ & $\begin{array}{l}\text { Soil application of } \\
\text { Carbofuran } 3 G \text { plus } \\
\text { two sprays with } \\
\text { spinosad } 45 \% \mathrm{SC}\end{array}$ & $\begin{array}{c}30 \mathrm{~kg} / \mathrm{ha} \\
+ \\
160 \mathrm{ml} / \mathrm{ha}\end{array}$ & 92.89 & 35.33 & 35330 & 11130 & 24200 & $01: 2.17$ \\
\hline $\mathbf{T}_{2-}$ & $\begin{array}{l}\text { Soil application of } \\
\text { Carbofuran } 3 G \text { plus } \\
\text { two sprays wit } \\
\text { Imidacloprid } \\
17.8 \% \text { SL }\end{array}$ & $\begin{array}{c}30 \\
\mathrm{Kg} / \mathrm{ha}+ \\
0.003 \%\end{array}$ & 101.56 & 44.00 & 44000 & 9562 & 34438 & 01:3.60 \\
\hline $\mathbf{T}_{3 .}$ & $\begin{array}{l}\text { Soil application of } \\
\text { Carbofuran } 3 \mathrm{G} \text { plus } \\
\mathbf{1}^{\text {st }} \text { spray spinosad } \\
\mathbf{4 5 \%} \mathrm{SC} \text { plus } \\
\mathbf{2}^{\text {nd }} \text { spray } \\
\text { imidacloprid } 17.8 \% \\
\text { SL }\end{array}$ & $\begin{array}{c}30 \mathrm{~kg} / \mathrm{ha} \\
+ \\
160 \mathrm{ml} / \mathrm{ha} \\
+ \\
0.003 \%\end{array}$ & 97.12 & 39.56 & 39560 & 10346 & 29214 & $01: 2.82$ \\
\hline $\mathbf{T}_{4 .}$ & $\begin{array}{l}\text { Soil application of } \\
\text { Carbofuran } 3 G \\
\text { plus two sprays } \\
\text { with NSKE 5\% }\end{array}$ & $\begin{array}{c}30 \\
\mathrm{Kg} / \mathrm{ha}+ \\
5 \mathrm{ml} / \mathrm{lit}\end{array}$ & 90.00 & 32.44 & 32440 & 12960 & 19480 & $01: 1.50$ \\
\hline $\mathbf{T}_{5-}$ & $\begin{array}{l}\text { Soil application of } \\
\text { Carbofuran } 3 \mathrm{G} \text { plus } \\
\text { two sprays with } \\
\text { Neem oil } 0.03 \%\end{array}$ & $\begin{array}{c}30 \mathrm{Kg} / \mathrm{ha} \\
+ \\
5 \mathrm{ml} / \mathrm{lit}\end{array}$ & 93.56 & 36 & 36000 & 13650 & 22350 & 01:1.64 \\
\hline$T_{6-}$ & $\begin{array}{l}\text { Soil application of } \\
\text { Carbofuran } 3 G \\
\text { plus } 1^{\text {st }} \text { spraywith } \\
\text { NSKE 5\% plus } 2^{\text {nd }} \\
\text { spray with Neem oil } \\
0.03 \%\end{array}$ & $\begin{array}{c}30 \\
\mathrm{Kg} / \mathrm{ha}+ \\
5 \mathrm{ml} / \mathrm{lit}\end{array}$ & 88.89 & 31.33 & 31330 & 13305 & 18025 & $01: 1.35$ \\
\hline & Control & & 57.56 & - & - & - & - & - \\
\hline S.E I & & & 0.364 & & & & & \\
\hline C.D. & $5 \%$ & & 1.135 & & & & & \\
\hline C.V. & & & 15.81 & & & & & \\
\hline
\end{tabular}


Table.3 Effect of integrated management on yield attributing characters of chilli

\begin{tabular}{|c|c|c|c|c|c|c|c|}
\hline & & & & \multicolumn{4}{|c|}{ Rabi,2015-16cropping season } \\
\hline & Treatments & Dose & $\begin{array}{l}\text { Mean } \\
\text { plant } \\
\text { height } \\
(\mathrm{cm})\end{array}$ & $\begin{array}{c}\text { Mean no. of } \\
\text { branches/pl } \\
\text { ant } \\
\text { (No.) }\end{array}$ & $\begin{array}{l}\text { Mean } \\
\text { length/fruit } \\
(\mathrm{cm})\end{array}$ & $\begin{array}{l}\text { Mean } \\
\text { breadth/ } \\
\text { fruit } \\
(\mathrm{cm})\end{array}$ & $\begin{array}{c}\text { Mean } \\
\text { fruit } \\
\text { Weigh/ } \\
\text { Plant } \\
\text { (gm) }\end{array}$ \\
\hline $\mathbf{T}_{1-}$ & $\begin{array}{l}\text { Soil application of } \\
\text { Carbofuran } 3 \mathrm{G} \text { plus } \\
\text { two sprays with } \\
\text { spinosad } 45 \% \mathrm{SC}\end{array}$ & $\begin{array}{l}30 \mathrm{~kg} / \mathrm{ha}+ \\
160 \mathrm{ml} / \mathrm{ha}\end{array}$ & 37.89 & 5.00 & 6.12 & 0.74 & 44.45 \\
\hline $\mathbf{T}_{2-}$ & $\begin{array}{l}\text { Soil application of } \\
\text { Carbofuran } 3 \mathrm{G} \text { plus } \\
\text { two sprays wit } \\
\text { Imidacloprid } 17.8 \% \mathrm{SL}\end{array}$ & $\begin{array}{l}30 \mathrm{Kg} / \mathrm{ha}+ \\
0.003 \%\end{array}$ & 39.87 & 5.70 & 6.21 & 0.98 & 44.92 \\
\hline $\mathbf{T}_{3}$ & $\begin{array}{l}\text { Soil application of } \\
\text { Carbofuran } 3 G \text { plus } \\
1^{\text {st }} \text { spray spinosad } \\
45 \% \text { SC }+2^{\text {nd }} \text { spray } \\
\text { imidacloprid } 17.8 \% \mathrm{SL}\end{array}$ & $\begin{array}{l}30 \mathrm{~kg} / \mathrm{ha}+ \\
160 \mathrm{ml} / \mathrm{ha} \\
+ \\
0.003 \%\end{array}$ & 39.67 & 5.36 & 6.19 & 0.75 & 44.84 \\
\hline & $\begin{array}{l}\text { Soil application of } \\
\text { Carbofuran } 3 G \\
\text { plustwo spray with } \\
\text { NSKE 5\% }\end{array}$ & $\begin{array}{l}30 \mathrm{Kg} / \mathrm{ha}+ \\
5 \mathrm{ml} / \mathrm{lit}\end{array}$ & 37.77 & 4.65 & 5.78 & 0.74 & 40.15 \\
\hline $\mathbf{T}_{5-}$ & $\begin{array}{l}\text { Soil application of } \\
\text { Carbofuran 3Gplus } \\
\text { two spray with Neem } \\
\text { oil } 0.03 \%\end{array}$ & $\begin{array}{l}30 \mathrm{Kg} / \mathrm{ha}+ \\
5 \mathrm{ml} / \mathrm{lit}\end{array}$ & 34.66 & 4.33 & 4.76 & 0.72 & 39.75 \\
\hline $\mathbf{T}_{6-}$ & $\begin{array}{l}\text { Soil application of } \\
\text { Carbofuran } 3 G \text { plus } \\
1^{\text {st }} \text { spray with NSKE } \\
5 \% \text { plus } 2^{\text {nd }} \text { spray with } \\
\text { Neem oil } 0.03 \%\end{array}$ & $\begin{array}{l}30 \mathrm{Kg} / \mathrm{ha}+ \\
5 \mathrm{ml} / \mathrm{lit}\end{array}$ & 36.99 & 4.43 & 5.38 & 0.71 & 39.29 \\
\hline $\mathbf{T}_{7}$ & Control & & 32.25 & 3.90 & 4.39 & 0.45 & 33.81 \\
\hline S.En & & & 1.54 & 0.34 & 0.35 & 0.08 & 2.06 \\
\hline C.D. & t $5 \%$ & & 4.84 & 1.07 & 1.21 & 0.25 & 6.43 \\
\hline C.V. & & & 7.27 & 12.54 & 12.34 & 18.33 & 8.72 \\
\hline
\end{tabular}


Fig.1 Integrated disease management of chilli leaf curl disease and green fruit yield of chilli

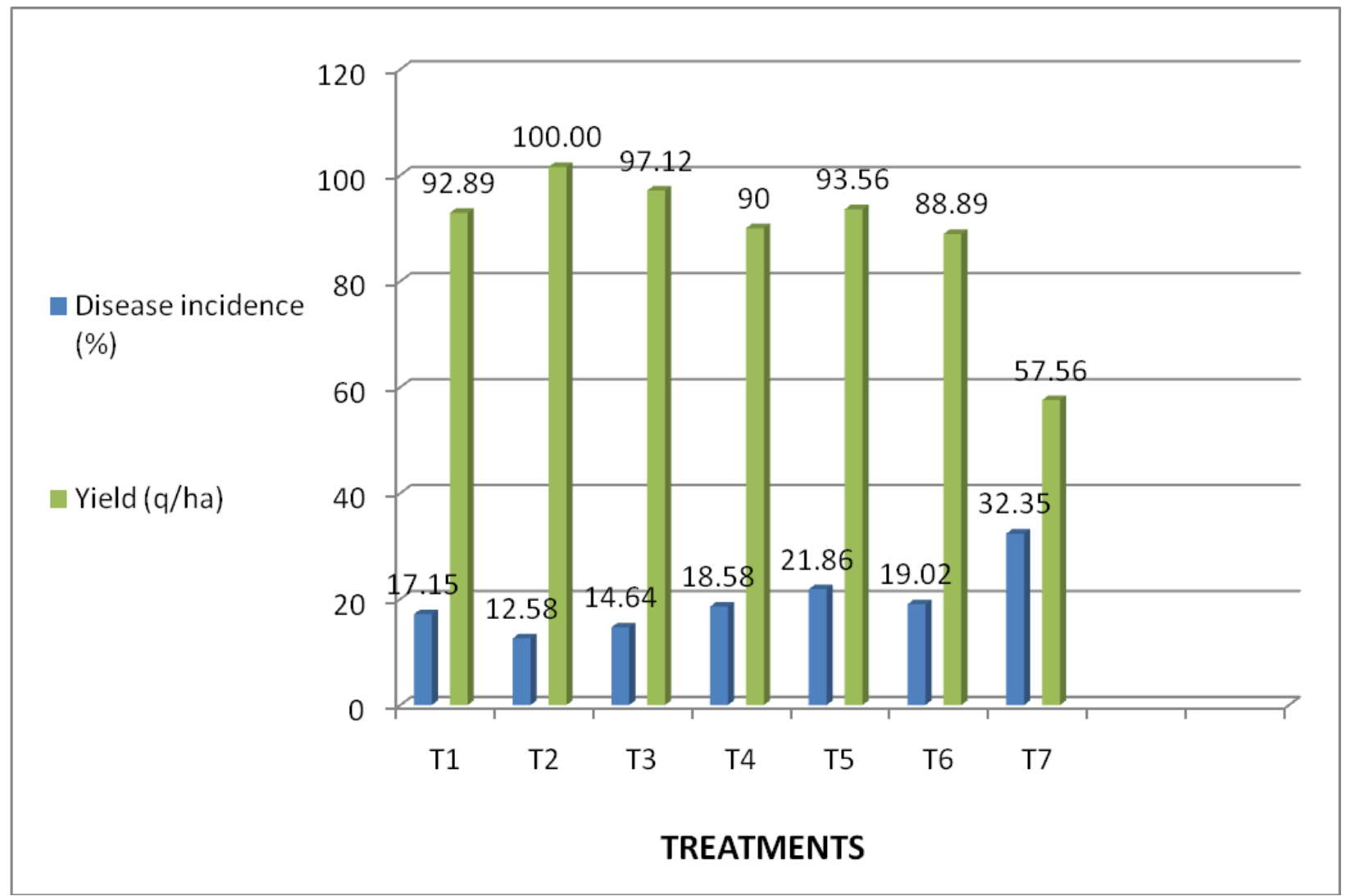

Rabi (2015-16) season

Effect of integrated management on incidence of leaf curl virus disease and fruit yield of chilli was studied by using different insecticides and neem products viz., soil application of Carbofuran 3GImidacloprid $17.8 \%$ SL, Spinosad $45 \%$ SC, NSKE 5\%,and Neem oil $0.03 \%$. Among these combinations of Carbofuran 3G @30 Kg/ha as soil application plus two sprays with Imidacloprid $17.8 \%$ SL @ $0.003 \%$ recorded minimum mean disease incidence of $12.58 \%$ and highest mean fruit yield of $101.56 \mathrm{q} / \mathrm{ha}$. Maximum disease reduction over control (61.12\%)was observed by one times soil application of Carbofuran 3G @ $30 \mathrm{Kg} / \mathrm{ha}$ plus two sprays of Imidacloprid 17.8\%SL @ $0.003 \%$.It also recorded highest increase in yield over control $(76.44 \%)$. Combination of Soil application of Carbofuran 3G plus NSKE and combination of Carbofuran $3 \mathrm{G}$ plus
Neem oil gave poor results as compared to combination of insecticides. Considering costbenefit ratio, higher cost-benefit ratio of 1:3.6 was obtained by soil application of Carbofuran 3G plus two sprays with Imidacloprid followed by soil application of Carbofuran plus first spray with Spinosad plus second spray with Imidacloprid which observed cost-benefit ratio of 1:2.82.

Maximum mean plant height, number of branches per plant, fruit length, fruit breadth, fruit weight was recorded by soil application of Carbofuran 3G plus two sprays with Imidacloprid. These phenotypic characters were statistically significant in all the treatments. These results are similar with report of earlier several workers. Mallapur (2004) reported maximum dry chilli yield in GCK (garlic chilli kerosene) extract + 
Nimbicidine treated plots. Thus, the results were clearly emphasizing the possibility of reducing pesticide load in the pest ridden crop like chilli. These practices also promise production of pesticide - free chilli, which is a major deterrent in the international market. Rajasri et al., (1991) evaluated six synthetic insecticide, four neem preparations and one chitin inhibitor as foliar spray against chilli pests complex including mite, $P$. latus under field conditions in Andhra Pradesh during 1989 and found chitin inhibitors, dulhar least effective against P.latus. Triazophos proved the best among the synthetics, whereas neem preparations gave poor results as compared to synthetic insecticides. Results on the effectiveness of neem based treatments on the management of $P$. latus in red chilli revealed that all the integrated treatments, without or with the inclusion or one spray of phosphamidon at 45 days after transplanting (DAT) were highly effective and safe to natural enemies (Chakraborti, 2000). Of the important components of IPM for vegetable production (Rai and Singh, 2008) pesticide application is one. In a field trial during summer in West Bengal, detopping of affected shoots at 16 DAT followed by application of neem cake $1 \mathrm{~kg} / \mathrm{m} 2$ at 20-days interval or foliar application of neem oil (10 $\mathrm{ml} /$ litre)+ Azadiractin(4ml/litre) at 7 DAT and need based application of Profenofos ( $2 \mathrm{ml} /$ litre) effectively controlled mites and thrips on chilli and were quite safe to natural enemies (Chakraborti, 2004). Neem products controlled the pest chilli thrips (Scirothrips dossalis Hood) effectively (Keisa and Varatharanjan, 1995). Sprays of Imidacloprid $200 \mathrm{SL}(0.5 \mathrm{ml} / \mathrm{l})$ mixed with neem oil or $P$. pinnata oil $(0.2 \%)$ were more effective (Sidhu, 2008).

In conclusion, it was apparent from the effect of integration of insecticides with plant products in field condition that integration effectively reduced the disease incidence as compared to control. Therefore, the investigation strongly recommends the soil application of Carbofuran 3G 30kg/ha @plus two sprays with Imidacloprid17.8\% SL @ $0.003 \%$ against the vector activities to reduce chilli leaf curl disease complex.

\section{Acknowledgement}

The authors are highly grateful to the Department of Plant Pathology, Birsa Agricultural University, Ranchi, Jharkhand for providing the necessary facilities during the course of study.

\section{References}

Chakraborti, S. (2000). Neem based integrated schedule for the control of vectors causing apical leaf curling in chilli. Pest Mngt. Econ.Zoolo.8 (1): 7984.

Chakraborty, S. (2004). Sustainable management of apical leaf culing in chilli. J. Appl.Zoo. Res. 15 (1): 34-36.

Keisa, J. T. and Varatharajan, R. (1995). Efficacy of two neem products in the field control of Scirtothrips dorsalis Hood (Thysanoptera) on Capsicum annum. Indian J. Plant Prot. 23: 166168.

Mallapur, C.P. (2004). Management of chilli pests through indigenous materials. Karnataka Journal of Agricultural Sciences, 17 (2): 315-319.

Nene, Y.L. (1972). A survey of viral diseases of pulse crops in Uttar Pradesh. G.B. Pant. Univ. Agric. Technol. Pantnagar Res.Bull., 4, 911.

Rai, S. N. and Singh. (2008). Efficacy of some Acaricides/ Insecticides against Tetranychus urticae Koch. on Okra. Indian journal of Entomology, 70(2): 169-171.

Rajasri, M., Reddy, G.P.V., Krishnmurthy, M. and Prasad, V.D. (1991). Bioefficacy of 
certain newer insecticides and neem products against chilli pest complex. Indian J. Cocoa Arecanut Spices, 15:42-44

Senanayake, D. M. J. B., B. Mandal, S. Lodha and A. Verma, A. (2006). First report of chillileaf curl affecting chilli in India. $J$. Food Agric. Environ., 4: 171-174.

Sidhu, A.S. (2008). Annual Report 20082009, Indian Institute of Horticultural Research, Hessarghatta, Banglore.

Singh, R. P., Devakumar, C. and Dhingra, S. (1988). Activity of neem (Azadirachta indica A. Juss.) seed kernel extracts against the mustard aphid, Lipaphiserysimi. Phytoparasitica, 16: 225-230.
Vanisree, K., Upendhar, S., Rajasekhar, P., Ramachandra Rao, G. and Srinivasa Rao, V. (2013). Field evaluation of certain newer insecticides against chilli thrips, Scirtithrips dorsalis (Hood). Science Park Research Journal, 1(20): 1-13.

Venkatesh, H.M., Muniappa, V., Ravi, K.S. and Prasad, K. P.R. (1998). Management of chilli leaf curl complex. In: Advances in IPM for horticultural crops. (ed) Reddy, P.P., Kumar, N.K.K. and Varghese, A., In: Proceedings of the First National Symposium on Pest Management in Horticulture Crops: Environmental Implications and Thrusts, Bangalore, India, 15-17, 111117.

\section{How to cite this article:}

Zeeshan, N. and Kudada, N. 2019. Integrated Management of Chilli Leaf Curl Disease Complex in Ranchi Region in Jharkhand, India. Int.J.Curr.Microbiol.App.Sci. 8(01): 945-953. doi: https://doi.org/10.20546/ijcmas.2019.801.103 